\title{
ORGANOTIN(IV) DERIVATIVES OF 3,4-(METHYLENE- DIOXY)PHENYLACETIC ACID: SYNTHESIS, SPECTROSCOPIC CHARACTERIZATION AND IN VITRO ANTITUMOUR PROPERTIES
}

\author{
Carlos Camacho Camachola,2, Dick de Vos³, Bernard Mahieu4, Marcel Gielen*1a, \\ Martine Kemmer ${ }^{1 \mathrm{a}}$, Monique Biesemans ${ }^{1 \mathrm{a}, 1 \mathrm{~b}}$, and Rudolph Willem ${ }^{1 \mathrm{a}, 1 \mathrm{~b}}$ \\ ${ }^{1}$ Free University of Brussels VUB, Pleinlaan 2, B-1050 Brussels, Belgium \\ a AOSC Department, Faculty of Applied Sciences; ${ }^{\text {b }}$ High Resolution NMR Centre \\ 2 Present address: Universidad Autonoma Metropolitana. Unidad Xochimilco, Departamento de Sistemas \\ Biologicos, Calzada del Hueso 1100, Col. Villa Quietud, 04960 Mexico D. F. \\ 3 PCH Nederland, Pharmachemie BV, Medical Department, PO Box 552, \\ NL-2003 RN Haarlem, The Netherlands \\ 4 Universite Catholique de Louvain, Unite CPMC, Bâtiment Lavoisier, Place Pasteur, \\ B-1348 Louvain-la-Neuve, Belgium
}

\begin{abstract}
The triphenyltin and tri-n-butyltin 3,4-(methylenedioxy)phenylacetates as well as the tetra- $n$-butylbis[3,4(methylenedioxy)phenylacetato]distannoxane dimer have been synthesized and characterized by ${ }^{1} \mathrm{H},{ }^{13} \mathrm{C}$, ${ }^{117} \mathrm{Sn} \mathrm{NMR},{ }^{119 \mathrm{~m} S n}$ Mössbauer and mass spectroscopy. The compounds have been screened against a panel of tumour cell lines of human origin.
\end{abstract}

\section{Introduction}

Many di- $n$-butyl-, tri- $n$-butyl- and triphenyltin carboxylates are biologically active and display interesting antitumour activity in vitro against cell lines of human origin [1-3].

This paper continues our series [4-9] on organotin carboxylates with antitumour activity. The carboxylic acid selected, 3,4-(methylenedioxy)phenylacetic acid, is characterized by a bicyclic structure which is also present in analogues of the DNA-binding antitumour agent DC 81 [10]. A similar bicyclic skeleton is found in structures of selective phosphodiesterase inhibitors [11] and in antitumour drugs for the treatment of benign prostatic hyperplasia [12-13].

We report here the synthesis and properties of three novel organotin(IV) derivatives of 3,4(methylenedioxy)phenylacetic acid (Schemes 1 and 2). These compounds have been characterized from the ${ }^{1} \mathrm{H},{ }^{13} \mathrm{C},{ }^{117} \mathrm{Sn}$ NMR, ${ }^{119 m} \mathrm{Sn}$ Mössbauer and mass spectra.

The antitumour activity in vitro of these compounds has been screened against seven tumour cell lines of human origin. The results are compared with those of other organotin phenylacetates with different aromatic substitution patterns, investigated previously [14-15]. This paper addresses in particular the triphenyltin carboxylate 1, belonging to a compound category on which autitumour data were scarce until recently [14$15]$.

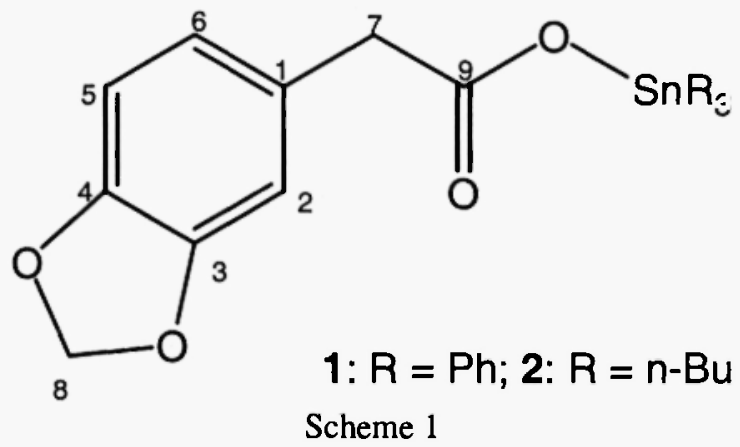

\section{Results and Discussion}

Triorganotin carboxylates $\mathrm{R}^{\prime} \mathrm{CO}_{2} \mathrm{SnR}_{3}$ are known to adopt a variety of motifs in the solid state [16-17]. For derivatives in which the organic residue does not contain an additional potential donor atom, the majority of the structures adopt one of two basic motifs (A, B) (Scheme 3). In the solid state, motif A is monomeric, often with a five-coordinated tin atom, while motif $B$ is polymeric with, by definition, likewise fivecoordinated tin. 


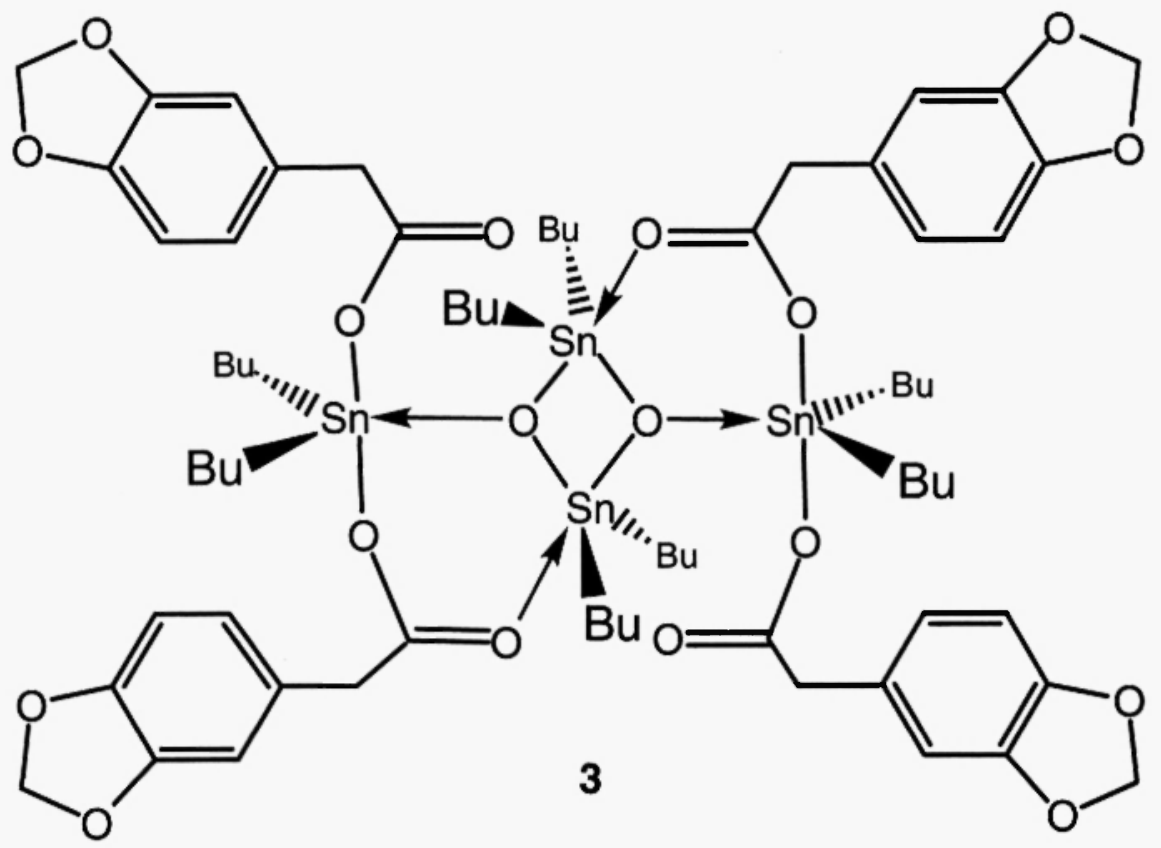

Scheme 2

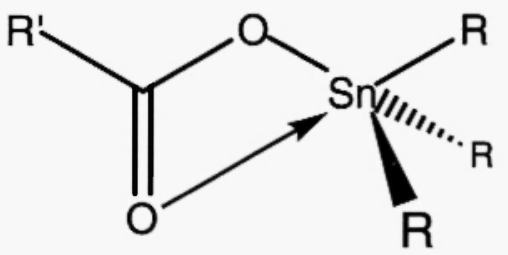

(A)

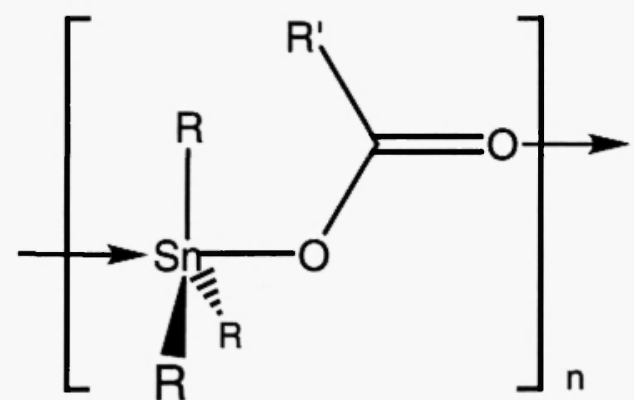

(B)

Scheme 3

However, in solution, such structures appear four-coordinate, the additional coordination from the carbonyl oxygen to tin being lost [15]. The synthesis of the triorganotin carboxylates 1 and $\mathbf{2}$ was achieved in benzene by condensing 3,4-(methylenedioxy)phenylacetic acid with triphenyltin hydroxide and tri-n-butyltin acetate respectively. Dicarboxylatotetraorganodistannoxane dimers of the type $\left(\mathrm{R}^{\prime} \mathrm{COO}\left(\mathrm{R}_{2} \mathrm{Sn}\right)-\mathrm{O}-\left(\mathrm{SnR}_{2}\right) \mathrm{OOCR}^{\prime}\right\}_{2}$, characterized by ladder structures, are the subject of great interest because of both their structural diversity in the crystalline state [16-18] and their interesting biological activities [19-23]. In principle they are easily characterized in solution by standard NMR techniques as their solution structure (Scheme 2) gives rise to two ${ }^{119} \mathrm{Sn}$ resonances of equal intensities, appearing in the ${ }^{119} \mathrm{Sn}$ chemical shift range -170 to $-230 \mathrm{ppm}$ and exhibiting unresolved ${ }^{2} \mathrm{~J}\left({ }^{119} \mathrm{Sn}-\mathrm{O}-{ }^{119 / 117} \mathrm{Sn}\right)$ coupling satellites [18-23].

The starting materials for the synthesis of the di- $n$-butyltin carboxylate 3 are di- $n$-butyltin oxide and 3,4(methylenedioxy)phenylacetic acid.

In general, different compounds can be synthesized depending on the acid/tin molar ratio engaged into the reaction. For the synthesis of [di-n-butyl(carboxylato)tin] oxides, a 1/1 ratio is used, while the preparation of di- $n$-butyltin dicarboxylates requires a $1 / 2$ ratio. 
In the present case, only the $\left\{\left[\mathrm{Bu}_{2} \mathrm{Sn}(\mathrm{OCOR})\right]_{2} \mathrm{O}\right\}_{2}$ compound is isolated after recrystallization from either of the two procedures, as evidenced by the observed two ${ }^{117} \mathrm{Sn}$ NMR resonances of equal intensity (see below, table 3). Apparently, either only one equivalent of acid can be consumed or the diorganotin dicarboxylates formed can undergo a hydrolysis to yield the dimeric distannoxanes:

\section{$4 \mathrm{Bu}_{2} \mathrm{Sn}(\mathrm{OCOR})_{2}+2 \mathrm{H}_{2} \mathrm{O} \rightarrow\left\{\left[\mathrm{Bu}_{2} \mathrm{Sn}(\mathrm{OCOR})\right]_{2} \mathrm{O}\right\}_{2}+4 \mathrm{RCOOH}$}

The ${ }^{1} \mathrm{H}-\mathrm{NMR}$ data of compounds $\mathbf{1}$ to 3 are reported in table 1 .

Table 1: ${ }^{1} \mathrm{H}$ NMR data in $\mathrm{CDCl}_{3}$

\begin{tabular}{lccc}
\hline & $\mathbf{1}$ & $\mathbf{2}$ & $\mathbf{3}$ \\
\hline $\mathrm{H} 2, \mathrm{H} 5, \mathrm{H} 6$ & $(\mathrm{~m}) 6.69-6.77$ & (m) $6.72-6.79$ & $(\mathrm{~m}) 6.64-6.79$ \\
$\mathrm{H} 7$ & $(\mathrm{~s}) 3.62$ & 3.51 & $(\mathrm{~s}) 3.39$ \\
$\mathrm{H} 8$ & $(\mathrm{~s}) 5.89$ & $(\mathrm{~s}) 5.90$ & - \\
$\mathrm{H}(\mathrm{o})$ & $(\mathrm{m}) 7.64-7.73[61]$ & - & - \\
$\mathrm{H}(\mathrm{m}+\mathrm{p})$ & $(\mathrm{m}) 7.32-7.49$ & - & - \\
$\mathrm{H}(\alpha)$ & - & $(\mathrm{t}) 1.23(8)[61]$ & $(\mathrm{m}) 1.14-1.40$ \\
$\mathrm{H}(\beta)$ & - & $(\mathrm{m}) 1.50-1.65$ & $(\mathrm{~m}) 1.40-1.60$ \\
$\mathrm{H}(\gamma)$ & - & $(\mathrm{tq}) 1.30(7,7)$ & $(\mathrm{m}) 1.14-1.40$ \\
$\mathrm{H}(\delta)$ & $(\mathrm{t}) 0.89(7)$ & $(\mathrm{t}) 0.85(7)$ \\
\hline
\end{tabular}

${ }^{1} \mathrm{H}$ chemical shifts in $\mathrm{ppm}$ with respect to TMS; coupling constants in $\mathrm{Hz},{ }^{\mathrm{n} J}\left({ }^{1} \mathrm{H}-{ }^{1} \mathrm{H}\right)$ in parentheses. Abbreviations: $\mathrm{s}=$ singlet; $\mathrm{q}=$ quartet; $\mathrm{t}=$ triplet; $\mathrm{m}=$ complex pattern.

The assignment of the butyl and aromatic proton resonances is based on ${ }^{1} \mathrm{H}-{ }^{13} \mathrm{C}$ HMQC and HMBC experiments [24-26]. The proton resonances of the phenyl moieties of compound 1 as well as of the butyl moieties of compounds 2 and 3 appear as complex patterns; only unresolved ${ }^{n J}\left({ }^{1} \mathrm{H}_{-}{ }^{117 / 119} \mathrm{Sn}\right)$ coupling constants could be determined for compounds 1 and 2 . The ${ }^{13} \mathrm{C}$ NMR data are reported in table 2. For all compounds the assignment of the butyl and aromatic moieties are based on the above ${ }^{1} \mathrm{H}_{-}{ }^{13} \mathrm{C} \mathrm{HMQC}$ and ${ }^{1} \mathrm{H}$ ${ }^{13} \mathrm{C}$ HMBC spectra, combined with the ${ }^{\mathrm{nJ}}\left({ }^{13} \mathrm{C}-117 / 119 \mathrm{Sn}\right)$ coupling constants for compounds 1 and 2 . For the $\alpha, \beta$ and $\gamma$ carbons of the butyl moieties, compound 3 shows pairs of ${ }^{13} \mathrm{C}$ resonances with very similar chemical shifts, the resulting overlapping precluding the observation of ${ }^{n} \mathrm{~J}\left({ }^{13} \mathrm{C}-{ }^{117 / 119} \mathrm{Sn}\right)$ satellites for the $\beta$ and $\gamma$ carbons;, the $\alpha \mathrm{CH}_{2}$ moieties show broad ${ }^{13} \mathrm{C}$ resonances with the ${ }^{1} \mathrm{~J}\left({ }^{13} \mathrm{C}-{ }^{117 / 119} \mathrm{Sn}\right)$ coupling constants being nevertheless observable.

The ${ }^{117} \mathrm{Sn}-\mathrm{NMR}$ data are given in table 3 . Compounds 1 and 2 exhibit a single resonance. The ${ }^{117} \mathrm{Sn}$ chemical shifts and the ${ }^{1} \mathrm{~J}\left({ }^{13} \mathrm{C}-117 / 1{ }^{19} \mathrm{Sn}\right)$ coupling constants are characteristic for four-coordination in solution [15]. Compound 3 exhibits the two ${ }^{117}$ Sn NMR resonances of equal intensities characteristic for the five-coordinate endocyclic and exocyclic tin atoms of the dimeric carboxylatodistannoxane dimeric structure. Mössbauer spectroscopy provides useful information on the geometry around the tin nucleus in the solid state $[15,27]$ when no crystals suitable for X-ray diffraction can be obtained, as here. In particular, quadrupole splitting (Q.S.) values often allow discrimination between tetrahedral, trigonal bipyramidal and cis or trans octahedral arrangements, each of them being characterized by a characteristic value range (tetrahedral: 2.1 $2.4 \mathrm{~mm} / \mathrm{s}$; trigonal bipyramidal: $3.0-4.1 \mathrm{~mm} / \mathrm{s}$; cis-octahedral: $1.7-2.2 \mathrm{~mm} / \mathrm{s}$; trans-octahedral: $3.5-4.2$ $\mathrm{mm} / \mathrm{s})$.

Compounds 1 and 2 are characterized by a single doublet, revealing the occurence of only one type of tin atom in the solid state, while compound 3 is best fitted into two doublets of equal intensities. These results are in agreement with the ${ }^{117} \mathrm{Sn}-\mathrm{NMR}$ data.

The tin atom of compounds 1 (Q.S. $=3.43 \mathrm{~mm} / \mathrm{s})$ and $2(\mathrm{Q} . S .=3.61 \mathrm{~mm} / \mathrm{s})($ see table 4$)$ is obviously fivecoordinate. However, there is a striking difference in the absorption intensities of compound $1(0.9 \%)$ and 2 (7\%), suggesting a different structural arrangement in the solid phase. Partial quadrupole splitting (p.q.s.) calculations for compound 2, considered as a polymeric five coordinated entity with planar $\mathrm{SnR}_{3}$ moieties and two apical oxygen atoms (motif B, Scheme 3), yield a Q.S. value of $3.67 \mathrm{~mm} / \mathrm{s}$, in agreement with the Q.S. observed $(3.62 \mathrm{~mm} / \mathrm{s})$.

The strong absorption percentage of compound $\mathbf{2}$ is also in favour of the proposed polymeric arrangement. On the other hand, a similar p.q.s. calculation is much less satisfactory for compound 1. This discrepancy, and especially the much lower resonant absorption fraction observed, suggests a motif A-structure in the case of this triphenyltin derivative (Scheme 3). Compound 3 exhibits a Mössbauer spectrum which can be satisfactorily fitted into two doublets of equal intensities. The larger one can be assigned to the endocyclic tin atoms which could be either trigonal bipyramidal (Scheme 2) or octahedral with a weak additional 
coordination from the carbonyl oxygen to tin. The narrower one is assigned to the commonly trigonal bipyramidal exocyclic tin atoms. The isomer shifts were found in the usual range $1.44-1.48 \mathrm{~mm} / \mathrm{s}$ for tri- $n$ butyltin compounds and $1.25-1.30 \mathrm{~mm} / \mathrm{s}$ for triphenyltin species [15].

Table 2: ${ }^{13} \mathrm{C}$ NMR data in $\mathrm{CDCl}_{3}$

\begin{tabular}{|c|c|c|c|}
\hline & 1 & 2 & 3 \\
\hline $\mathrm{Cl}$ & 129.3 & 130.2 & 130.3 \\
\hline $\mathrm{C} 2$ & 110.4 & 110.4 & 110.3 \\
\hline C3 & 148.2 & 148.2 & 148.2 \\
\hline C4 & 147.1 & 146.9 & 146.9 \\
\hline $\mathrm{C} 5$ & 108.8 & 108.6 & 108.6 \\
\hline C6 & 123.0 & 122.8 & 122.8 \\
\hline $\mathrm{C} 7$ & 41.5 & 42.3 & 44.0 \\
\hline $\mathrm{C} 8$ & 101.5 & 101.4 & 101.5 \\
\hline C9 & 178.8 & 177.6 & 178.1 \\
\hline $\mathrm{C}(\mathrm{i})$ & $138.7[646 / 617]$ & & \\
\hline$C(0)$ & $137.5[48]$ & & \\
\hline$C(m)$ & 129.5 [64] & & \\
\hline$C(p)$ & $130.8[12]$ & & \\
\hline$C(\alpha)$ & & $17.1[356 / 340]$ & $\begin{array}{l}29.2[508] \\
26.4[528 / 512]\end{array}$ \\
\hline$C(\beta)$ & & $28.4[21]$ & 28.1 \\
\hline$C(\gamma)$ & & $27.6[64]$ & $\begin{array}{l}21.8 \\
27.4\end{array}$ \\
\hline & & & 27.3 \\
\hline$C(\delta)$ & & 14.2 & 14.2 \\
\hline
\end{tabular}

${ }^{13} \mathrm{C}$ chemical shifts in ppm with respect to TMS; ${ }^{\mathrm{nJ}}\left({ }^{13} \mathrm{C}-{ }^{117 / 119} \mathrm{Sn}\right)$ coupling constants between square brackets.

Table 3: ${ }^{117} \mathrm{Sn}$ NMR data in $\mathrm{CDCl}_{3}$

\begin{tabular}{ccc}
\hline $\mathbf{1}$ & $\mathbf{2}$ & $\mathbf{3}$ \\
\hline-108.2 & 111.6 & -207.5 \\
& & -216.3 \\
& $\{114\}$ \\
\hline
\end{tabular}

Chemical shifts in ppm with respect to $\left(\mathrm{CH}_{3}\right)_{4} \mathrm{Sn} .{ }^{2} \mathrm{~J}\left({ }^{117} \mathrm{Sn}-\mathrm{O}-{ }^{117 / 119} \mathrm{Sn}\right)$ coupling constants between curly brackets.

Table 4: ${ }^{119 m}$ Sn Mössbauer parameters

\begin{tabular}{ccc}
\hline & IS & QS \\
\hline $\mathbf{1}$ & 1.29 & 3.43 \\
$\mathbf{3}$ & 1.47 & 3.62 \\
& 1.33 & 3.72 \\
\end{tabular}

QS $\left(\mathrm{mm} \mathrm{s}^{-1}\right)$ : quadrupole splitting; IS $\left(\mathrm{mm} \mathrm{s}^{-1}\right)$ : isomer shift relative to $\mathrm{Ca}^{119} \mathrm{SnO}_{3}$.

The electrospray mass spectra of the three compounds are fully compatible with the proposed structures. The following fragment-ion clusters were observed (masses given based on ${ }^{1} \mathrm{H},{ }^{12} \mathrm{C},{ }^{16} \mathrm{O}$ and ${ }^{120} \mathrm{Sn}$ ): compound 1: $453\left(\mathrm{RCOOSnPh}_{2}\right)^{+}$; compound 2: $761\left(\mathrm{M}+\mathrm{Bu}_{3} \mathrm{Sn}\right)^{+}, 413\left(\mathrm{RCOOSnBu}_{2}\right)^{+}$and $291\left(\mathrm{Bu}_{3} \mathrm{Sn}\right)^{+}$; compound 3: $945\left(\mathrm{RCOOSn}_{3} \mathrm{O}_{2} \mathrm{Bu} \mathrm{u}_{6}+\mathrm{CH}_{3} \mathrm{OH}\right)^{+}, 913\left(\mathrm{RCOOSn}_{3} \mathrm{O}_{2} \mathrm{Bu}_{6}\right)^{+}, 765\left(\mathrm{CH}_{3} \mathrm{COOSn}_{3} \mathrm{O}_{2} \mathrm{Bu}_{6}\right)^{+}, 751$ $\left(\mathrm{HCOOSn}_{3} \mathrm{O}_{2} \mathrm{Bu}_{6}\right)^{+}, 663\left(\mathrm{RCOOSn}_{2} \mathrm{OBu}_{4}\right)^{+}$.

\section{Antitumour activity}

The compounds 1 - $\mathbf{3}$ were screened in vitro against seven human cancer cell lines of human origin, MCF-7 (mammary cancer), EVSA-T (mammary cancer), WiDr (colon cancer), IGROV (ovarian cancer), M19 (melanoma), MEL A498 (renal cancer) and H226 (lung cancer). The $\mathrm{ID}_{50}$ values given in table 5 are compared with those [28] of some clinically used reference compounds, doxorubicine (DOX), cis-platin (CPT), 5-fluorouracil (5-FU), methotrexate (MTX) and etoposide (ETO).

Table 5 reveals that compounds 1-3 are more active than cis-platin, 5-fluorouracil and etoposide. They show mostly a high cytotoxicity being generally comparably or less active than doxorubicin and methotrexate [29]. 
Compounds 1 and 2 are significantly less active than the corresponding triorganotin pentafluorophenylacetates [14] and the corresponding non-substituted phenylacetates [15].

Table 5: In vitro inhibition doses $\mathrm{ID}_{50}(\mathrm{ng} / \mathrm{mL})$ of compounds 1 - 3 against seven tumour cell lines of human origin.

\begin{tabular}{lccccccc}
\hline & A498 & EVSAT & H226 & IGROV & M19 & MCF7 & WiDr \\
\hline $\mathbf{1}$ & 36 & 22 & 36 & 32 & 35 & 34 & 37 \\
$\mathbf{2}$ & 110 & 40 & 70 & 51 & 64 & 82 & 41 \\
$\mathbf{3}$ & 116 & 55 & 113 & 55 & 75 & 128 & 307 \\
DOX & 90 & 8 & 199 & 60 & 16 & 10 & 11 \\
CPT & 2253 & 422 & 3269 & 169 & 558 & 669 & 957 \\
5-FU & 143 & 475 & 340 & 297 & 442 & 750 & 225 \\
MTX & 37 & 5 & 2287 & 7 & 23 & 18 & $<3$ \\
ETO & 1314 & 317 & 3934 & 580 & 505 & 2594 & 159 \\
\hline
\end{tabular}

MCF-7 (mammary cancer), EVSA-T (mammary cancer), WiDr (colon cancer), IGROV (ovarian cancer), M19 (melanoma), MEL A498 (renal cancer) and H226 (lung cancer); DOX (doxorubucin), CPT (cisplatin), 5-FU (5-fluorouracil), MTX (methotrexate), ETO (etoposide).

\section{Experimental part}

Syntheses

Compound 1 is prepared by mixing equimolar amounts of triphenyltin hydroxide $(734 \mathrm{mg}, 2 \mathrm{mmol})$ and $3,4-$ (methylenedioxy)phenylacetic acid ( $360 \mathrm{mg}, 2 \mathrm{mmol}$ ) in $50 \mathrm{ml}$ of benzene, in a $100 \mathrm{ml}$ flask equipped with a Dean-Stark funnel. The mixture is refluxed during $4 \mathrm{~h}$. The binary azeotrope benzene/water is distilled off down to $50 \%$ of the initial solvent volume. The remaining solution is evaporated under vacuum. Purification is achieved after two recrystallizations from $\mathrm{CH}_{2} \mathrm{Cl}_{2} /$ hexane, $3 / 1$. Yield: $73 \%, \mathrm{mp}$ : $101-103{ }^{\circ} \mathrm{C}$.

Compound 2 is prepared analogously from equimolar amounts of tributyltin acetate $(698 \mathrm{mg}, 2 \mathrm{mmol})$ and 3,4-(methylenedioxy)phenylacetic acid $(360 \mathrm{mg}, 2 \mathrm{mmol})$ under elimination of acetic acid. Yield: $80 \%$, mp: $56-58{ }^{\circ} \mathrm{C}$.

Compound 3 has been synthesized similarly by mixing di- $n$-butyltin oxide $(248 \mathrm{mg}, 2 \mathrm{mmol})$ and 3,4(methylenedioxy)phenylacetic acid $(360 \mathrm{mg}, 2 \mathrm{mmol})$ in $35 \mathrm{ml}$ of toluene and $12 \mathrm{ml}$ of ethanol. The ternary azeotrope toluene/ethanol/water is distilled off. The remaining solution is evaporated under vacuum. Purification is achieved after recrystallization from methanol. Yield: $71 \%$, mp: $60-61{ }^{\circ} \mathrm{C}$.

Spectroscopy

The NMR spectra were acquired on a Bruker DRX250 instrument equipped with a Quattro probe tuned to $250.13,62.93$ and $89.15 \mathrm{MHz}$ for ${ }^{1} \mathrm{H},{ }^{13} \mathrm{C}$ and ${ }^{117} \mathrm{Sn}$ nuclei respectively. ${ }^{-} \mathrm{H}$ and ${ }^{13} \mathrm{C}$ chemical shifts were referenced to the standard $\mathrm{Me}_{4} \mathrm{Si}$ scale from respectively the residual ${ }^{1} \mathrm{H}$ and ${ }^{13} \mathrm{C}-{ }^{2} \mathrm{H}$ solvent resonances of chloroform $\left(\mathrm{CHCI}_{3}, 7.23\right.$ and $\mathrm{CDCl}_{3}, 77.0 \mathrm{ppm}$ for ${ }^{1} \mathrm{H}$ and ${ }^{13} \mathrm{C}$ nuclei, respectively). The ${ }^{117} \mathrm{Sn}$ resonance frequencies were calculated from the absolute reference $\Xi\left({ }^{117} \mathrm{Sn}\right) 35.632295$. Gradient enhanced $2 \mathrm{D}{ }^{1} \mathrm{H}-{ }^{13} \mathrm{C}$ HMQC and HMBC correlation spectra were acquired using the pulse sequence of the Bruker program library, as described recently [30].

The Mössbauer spectra were recorded as described elsewhere [31].

The electrospray mass spectra were recorded in the cationic mode on a Micromass Quattro II instrument coupled with a Masslynx system (ionisation in an electric field of $3,5 \mathrm{kV}$; source temperature: $80^{\circ} \mathrm{C}$; source pressure: $1 \mathrm{~atm}$; analyzer pressure: $\left.10^{-5} \mathrm{mbar}\right)[32-33]$.

Antitumour activity

The compounds were screened against seven human cancer cell lines. The screening is performed with aqueous solutions containing $1 \%$ of DMSO or ethanol by a literature procedure [29].

\section{Acknowledgments}

The authors thank the "Consejo Nacional de Ciencia y Tecnologia (CONACYT-Mexico)" and the Universidad Autonoma Metropolitana (UAM-X) for a research scholarship (C.C.C.). M.G., M.B. and R.W. are indebted to the Fund for Scientific Research Flanders (Belgium, Grants $n^{\circ}$ G.0192.98 (M.B., R.W.) and G.0074.00 (M.G.). M.K. thanks the "Ministere de l'Education Nationale du Luxembourg" (grants Nos. BFR93/051, BPU96/130, BPU97/138, BPU98/071 and the "Action Vaincre le Cancer du Luxembourg".

\section{References}

1. D. de Vos, R. Willem, M. Gielen, K. E. van Wingerden, K. Nooter, Metal-Based Drugs 5 (1998), 179.

2. M. Gielen, Coord. Chem. Rev. 151 (1996), 41.

3. M. Gielen, M. Biesemans, D. de Vos, R. Willem, J. Inorg. Biochem, in press

4. M. Gielen, H. Dalil, M. Biesemans, B. Mahieu, D. de Vos, R. Willem, Appl. Organomet. Chem. 13 (1999), 515. 
5. M. Gielen, H. Dalil, B, Mahieu, M. Biesemans, R. Willem, Appl. Organomet. Chem. 12 (1998), 855.

6. M. Gielen, H. Dalil, B. Mahieu, D. de Vos, M. Biesemans, R. Willem, Metal-Based Drugs 5 (1998), 265.

7. M. Kemmer, M. Gielen, M. Biesemans, D. de Vos, R. Willem, Metal-Based Drugs 5 (1998), 189.

8. M. Gielen, R. Willem, H. Dalil, D. de Vos, C. M. Kuiper, G. J. Peters, Metal-Based Drugs 5 (1998), 83.

9. R. Willem, H. Dalil, P. Broekaert, M. Biesemans, L. Ghys, K. Nooter, D. de Vos, F. Ribot , M. Gielen, Main Group Met. Chem. 20 (1997), 535.

10. D. E. Thurston, D. S. Bose, P. W. Howard, T. C. Jenkins, A. Leoni, P. G. Baraldi, A. Guiotto, B. Cacciari, L. R. Kelland, M. P. Foloppe, S. Rault, J. Med. Chem. 42 (1999), 1951.

11. T. Ukita, Y. Nakamura, A. Kubo, Y. Yamamoto, M. Takahashi, J. Kotera, T. Ikeo, J. Med. Chem. 42 (1999), 1293.

12. X. K. Zhu, J. Guan, Y. Tachibana, K. F. Bastow, S. J. Cho, H. H. Cheng, Y. C. Cheng, M. Gurwith, K. H. Lee, J. Med. Chem. 42 (1999), 2441.

13. D. Nagarathnam, J. M. Wetzel, S. W. Miao, M. R. Marzabadi, G. Chiu, W. C. Wong, X. Hong, J. Fang, C. Forray, T. A. Branchek, W. E. Heydorn, R. S. L. Chang, T. Broten, T. W. Schorn, C. Gluchowski, J. Med. Chem. 41 (1998), 5320.

14. R. Willem, A. Bouhdid, M. Biesemans, J. C. Martins, D. de Vos, E. R. T. Tiekink, M. Gielen, J. Organomet. Chem. 514 (1996), 203.

15. R. Willem, A. Bouhdid, B. Mahieu, L. Ghys, M. Biesemans, E. R. T. Tiekink, D. de Vos, M. Gielen. J. Organomet. Chem. 531 (1997), 151.

16. E. R. T. Tiekink, Appl. Organomet. Chem. 5 (1991), 1.

17. E. R. T. Tiekink, Trends Organomet. Chem. 1 (1994), 71.

18. T. P. Lockhart, W. F. Manders, E. M. Holt, J. Am. Chem. Soc. 108 (1986), 6611.

19. M. Gielen, E. R. T. Tiekink, A. Bouhdid, D. de Vos, M. Biesemans, I. Verbruggen, R. Willem, Appl. Organomet. Chem. 9 (1995), 639.

20. E. R. T. Tiekink, M. Gielen, A. Bouhdid, M. Biesemans, R. Willem, J. Organomet. Chem. 494 (1995), 247.

21. M. Gielen, A. Bouhdid, R. Willem, V. I. Bregadze, L. V. Ermanson, E. R. T. Tiekink, J. Organomet. Chem. 501 (1995), 277.

22. M. Gielen, A. El Khloufi, M. Biesemans, F. Kayser, R. Willem, Appl. Organomet. Chem. 7 (1993), 201.

23. M. Gielen, A. El Khloufi, M. Biesemans, R. Willem, Appl. Organomet. Chem. 7 (1993), 119.

24. A. Bax and M. F. Summers, J. Am. Chem. Soc. 108 (1986), 2093.

25. A. Bax and M. F. Summers, J. Magn. Reson. 67 (1986), 565.

26. A. Bax, R. H. Griffey, and B. H. Hawkins, J. Magn. Reson. 55 (1983) 301.

27. R. Willem, I. Verbruggen, M. Gielen, M. Biesemans, B. Mahieu, T. S. Basu Baul, E. R. T. Tiekink, Organometallics 17 (1998), 5758.

28. Y. P. Kepers, G. J. Peters, J. Van Ark-Otte, B. Winograd and H. M. Pinedo, Eur. J. Cancer 27 (1991) 897.

29. Cancer: principles and practice of oncology, V. T. De Vita Jr., S. Hellman, S. A. Rosenberg, Eds., 5th Ed. (1997), Lippincott-Raven Publ., Philadelphia].

30. R. Willem, A. Bouhdid, F. Kayser, A. Delmotte, M. Gielen, J. C. Martins, M. Biesemans, B.Mahieu, R. T. Tiekink, Organometallics 15 (1996), 1920.

31. M. Bouâlam, R. Willem, M. Biesemans, B. Mahieu, J. Meunier-Piret, M. Gielen, Main Group Met. Chem. $14(1991), 41$.

32. R. B. Costy, J. Tanura, B. Brusselman, Anal. Chem. 64 (1992) 1561.

33. G. Lawson, R.H. Dahm, N. Ostah, E. D. Woodland, Appl. Organomet. Chem. 10 (1996) 125.

\section{Received: May 8, 2000 - Accepted: May 16, 2000 - Received in publishable format: May 17, 2000}

